TH E N E W G I L D E A G E 


\section{SOCIAL INEQUALITY}

E D I T O R S

David B. Grusky stanFOR D UNIVERSITY

Paula England NEW YORK UNIVERSITY

E D I T O R A L B OA R D

Hans-Peter Blossfeld

Mary C. Brinton

Thomas DiPrete

Michael Hout

Andrew Walder

Mary C. Waters 


\section{THE NEW GILDED AGE}

The Critical Inequality Debates of Our Time

Edited by David B. Grusky and Tamar Kricheli-Katz

STANFORD UNIVERSITY PRESS

S T A N F OR D, C A L I F O R N I A 
Stanford University Press

Stanford, California

(C) 2012 by the Board of Trustees of the Leland Stanford Junior University. All rights reserved.

No part of this book may be reproduced or transmitted in any form or by any means, electronic or mechanical, including photocopying and recording, or in any information storage or retrieval system without the prior written permission of Stanford University Press.

Printed in the United States of America on acid-free, archival-quality paper

Library of Congress Cataloging-in-Publication Data

The new gilded age : the critical inequality debates of our time / edited by David B. Grusky and Tamar Kricheli-Katz. pages $\mathrm{cm}$

Includes bibliographical references and index.

ISBN 978-0-8047-5935-9 (alk. paper) -

ISBN 978-0-8047-5936-6 (pbk. : alk. paper)

1. Equality-United States. 2. Poverty-United States.

3. Discrimination-United States. 4. Equality. 5. Poverty.

I. Grusky, David B., editor of compilation. II. Kricheli-Katz, Tamar, editor of compilation.

HN90.S6N447 2012

3050973-dc23

Typeset by Newgen in 10/14 Sabon 
To Michelle Jackson 
